\title{
A magyar állampénzügyi rendszer rezilienciája a COVID-19 járvány kapcsán
}

\author{
Lentner Csaba \\ Nemzeti Közszolgálati Egyetem, Budapest, Magyarország \\ Károli Gáspár Református Egyetem, Budapest, Magyarország \\ Beérkezett: 2021. július 19. Elfogadva: 2021. augusztus 24.
}

\section{Összefoglalás}

\begin{abstract}
A COVID-19 járvány a magyar gazdaság teljesítményeit és pénzügyi egyensúlyát is gyengítette, ám a korábbról stabil államháztartási alapok következtében a negatív hatások csak átmenetinek vélelmezhetők. Magyarország 2010-2019 között egy sikeres állampénzügyi reformot hajtott végre, amely jó alapot ad a válság elleni védekezéshez. Ugyanakkor a járványválság még erősebben ráirányítja a figyelmet a magyar nemzetgazdaság versenyképességének erősebb javítására, az infláció fékezésére, a költségvetési egyensúly megfelelő keretek között tartására, és a kis- és középvállalati szektor mérethatékonyságának növelésére. A tanulmány bemutatja a válság alatti fiskális és jegybanki intézkedések vázát, és egyúttal utal a válság utáni időszak kihívásaira, amelyek a nemzetközi térből, s különösen a jegybanki politika megváltozásából fakadnak.
\end{abstract}

Kulcsszavak: járványválság, fiskális politika, monetáris mechanizmusok, versenyképesség

\section{Resilience of the Hungarian public finance system in relation to the COVID-19 epidemic}

\author{
Csaba Lentner \\ National University of Public Service, Budapest, Hungary \\ Károli Gáspár Reformed Church University, Budapest, Hungary
}

\begin{abstract}
Summary
The COVID-19 epidemic hit the position of the otherwise strong Hungarian economy. We could see an economic downturn and financial imbalance developed in the last one and half years. As in the recovery (post-crisis) period of the 2010 decade, the crisis is being addressed with the active involvement of the state and the central bank. However, in the course of managing the crisis, it arises that on the new growth trajectory to be built after the recovery period, the competitiveness aspects, especially in the small and medium-sized enterprise category, which plays a major role in Hungary, should be more efficient than in the previous decade. It is necessary to improve the size efficiency, liquidity and capital efficiency of the SME sector by means of fiscal regulation, and the allocation of state resources should be more strongly linked to the requirements of export capacity and innovative business conduct.

The decade after the 2007-2008 crisis - the previous recovery period - was characterized by the weak enforcement of fiscal policies in regulating and improving competitiveness, especially in Hungary, where change is essential. After 2013, Hungarian monetary policy also caught up with the international practice of quantitative easing, achieving significant results in improving both the financial balance and economic growth. However, the previous quantitative easing of the central bank, as well as the increase of budget expenditures on epidemiological expenditures, investments, normative budget annual subsidies from the European Union and subsidies from the European Reconstruction Fund, and even investment loans from our Eastern economic partners, generates an overheated economy, inflationary pressures, and external and balance of payments deficits. Added to this is the wage dynamics of the population, and the permanent and even increasing disbursement of family benefits during the crisis.
\end{abstract}


All in all, in the 2020s we will face a new financial-debt crisis, unemployment and labor shortage problems, the competitiveness problems of the small business sector, culminating in the reorganization of the world economy, new competitiveness aspects, it will be a rather complex task. Thus, the turn of competitiveness that has essentially failed in the context of an abundance of resources and consolidated macroeconomic conditions (2010-2019) must be implemented "uphill", it is only the time, will and opportunity to take its first steps. But the main lesson of the crises caused by the epidemics (also) is that the remaining economic entities have become stronger. And perhaps there is a chance to avoid falling into the trap of medium development through a new central bank policy that moderates inflation and truly enforces modernization considerations, as well as improving financial positions and improving economic positions (competitiveness).

Keywords: Epidemic Crisis, Fiscal Policy, Monetary Mechanisms, Competitiveness

\section{Bevezetés}

Földes Béla 1885-ben fogalmazta meg, hogy „a válságok igen gyászos következményekkel járnak. Pusztítanak egyéni és tárgyi értékeket, kiirtják a gazdasági élet alapföltételét, a bizalmat, keresetforrástól fosztják meg a társadalom számos tagját, nélkülözést, szegénységet szülnek, zavarják a népesség processzusát, és nem ritkán veszélyeztetik a nép erkölcsi erejét és számos erkölcsi bajt (bûntetteket, öngyilkosságokat) idéznek elő. De van a válságoknak némi jótékony hatásuk is: többnyire csak így nyer a gazdasági tevékenység ismét kellő arányokat és helyes irányt." (Földes 1885) A Magyarországon 2020 tavaszán „berobbanó” fertőzéses megbetegedések, s a velük járó óvintézkedések óhatatlanul visszavetették a gazdaság teljesítményét. A járványválság, s a vele adódó pénzügyi problémák - emberöltoónk számára - új típusú krízisnek minősülnek, hiszen nem a kormányzati vagy jegybanki térben alkalmazott esetleges hibákból fakadnak, így mondhatni nem belsô, hanem külső tényezôk hatására állnak elő. Ám a krízis kezelése, a helyreállítási, majd az újabb növekedési periódus elindítása a jegybanki, de különösen a fiskális eszköztár hatására következhet be, vagyis az állam válságkezelő szerepének újabb felértékelődő pályája célszerú, hogy érvényesüljön. Földes Bélára visszautalva konstatálhatjuk azonban, hogy ez a válság is negatív hatásokat keletkeztet mind a gazdaságra, mind a társadalomra. Ugyanakkor, mint minden krízis, az újrakezdés lehetôségét is magában hordozza, s ha építően állunk a folyamatokhoz, akkor úgy építjük újra a gazdaságot, hogy a korábbi időszakban elkövetetett hibákat próbáljuk kiküszöbölni, s legfóképpen az időközben megváltozó nemzetközi erővonalakhoz is alkalmazkodni. Vagyis, „a természet adta kihívás mindenképpen fel kell, hogy ébresszen mindannyiunkat, a pénzelmélet elemzőit, a pénzügypolitika és gazdaságpolitika irányítóit is, hogy a válság után semmiképp nem léphetünk vissza ugyanabba a folyóba. Számolnunk kell a világ megváltozott körülményeivel, és ahhoz kell igazítanunk ember alkotta szabályainkat, gazdasági elméleteinket és gazdaságpolitikai gyakorlatunkat is.” (Botos 2020)

\section{A járványválság előtti gazdaságpolitika}

A szocialista tervgazdasági rendszer utolsó évtizedének második felében megkezdett, teljes körü piacgazdasági átállást követő ún. nyers piacgazdasági átmenet két évtizede számos költségvetési és társadalmi problémát okozott. Kellő átmenet nélkül, ső́t, túl gyorsan került levezénylésre a gazdasági szektor tulajdonosi reformja, a belső termelők érdekeit nem akceptáló módon kerültek leépítésre a védővámok, sôt, a hazai vállalkozásokat és mezőgazdasági termelőket segítő jegybanki refinanszírozási eszközök is. A tervgazdaság végére kifejezetten gyengén teljesítő vállalatokat, mezőgazdasági szövetkezeteket a likviditási problémákkal és súlyos államadósság teherrel küzdő központi költségvetés egyre kevésbé tudta kisegíteni, így tömeges csődökre került sor, amely mintegy másfél millió ipari és mezőgazdasági munkahely megszúnését okozta, amiből súlyos társadalmi problémák keletkeztek. Egyidejűleg a lakosság felé megnyilvánuló szubvenciókat, mondhatni a paternalista szerepvállalást - gyengülő anyagi ereje függvényében - az állam gyors ütemben kezdte leépíteni. Mindezek következtében - Kornai János (2006) fogalomkészletét használva „transzformációs válság” következett be. Miáltal a piacgazdasági átmenet két évtizede folyamatos - nem csak az 1990-es évek első évtizedének közepéig - megingásokat produkált $(1995,2006,2008)$, s lényegében a társadalom és a hazai kkv-szektor jövedelmi, likviditási, tőkeellátottsági helyzete a rendszerváltozás kezdetén vélelmezett/elvárt szintet nem érte el, ezért inkább a „rendszerváltás rendszerválsága” (Lentner 2016) a 2010-ig tartó korszakra az átfogóbb, a lényeget jobban megragadó kifejezés.

A 2010-tôl bekövetkezô gazdasági vonalvezetés az előző két, két és fél évtized gazdasági filozófiájától lényegesen eltér. A gazdaság-, a pénz- és tôkepiac erősebb szabályozása érvényesül, s egy széles körú, a belső rezidenseknek előnyösebb, az adóeróképességhez jobban igazodó adóreform valósult meg. A költségvetési ellenorzés jogköre és módszertana kiszélesedett, a jó kormányzás eszközévé vált (Domokos 2019). A gyermekeket vállaló családok az előző évtizedeknél bőségesebb támo- 
gatási rendszerben (CSOK és más adókedvezmények) részesülnek, s a minimálbér és az átlagbér is a duplájára emelkedett. A korábban privatizált stratégiai ágazatok állami visszavásárlása jelentős méreteket öltött, különösen a közüzemi, energetikai és pénzügyi szektorban. 2013-tól következett be a monetáris politikai rendszerváltás, melynek során a jegybank az 1987-ben visszaállított kétszintú bankrendszer közel negyed évszázada után újra határozott refinanszírozási múveletekbe kezdett, vagyis a hazai kis- és középvállalkozások számára növekedési hitelprogramokat indított, a kereskedelmi bankokat pedig - szabályozási mechanizmusain keresztül - aktivizálta, mind a vállalati hitelezés, mind az államadósságfinanszírozás területén. A nemzetközi trendekhez is igazodó alacsony alapkamat pálya, s az említett mennyiségi lazítások hatására mind a gazdaság növekedése, mind a pénzügyi egyensúly helyreállta bekövetkezett. A jegybank elnökének megfogalmazása szerint „sereghajtóból újra éllovasok lettünk” (Matolcsy 2020a). A Trianon utáni száz év legsikeresebb évtizedét tudhatjuk magunk mögött (bővebben a száz évről: Virág 2020). Az aktív államvezérelt gazdasági politika a francia etatista, a II. világháború utáni Konrad Adenauer - Ludwig Erhard által vitt német mechanizmussal, de különösen a dualizmus fél évszázadának szubvencionáló, állami segédlettel végrehajtott kapitalizmusépítésével igen nagy mértékben hasonlatos logikájú (Lentner 2019).

A 2011-ben elfogadott Alaptörvény közpénzügyi fejezetének államadósság-csökkentést előtérbe helyező célkitűzése, s a hozzá kapcsolódó államháztartási gazdálkodási fegyelmet, pénzügyi stabilitást szolgáló sarkalatos törvények, melyek közül legfontosabbak talán a Stabilitási törvény, az Állami Számvevőszék múködéséról szóló jogszabály és a Magyar Nemzeti Bankra vonatkozó kétharmados törvény következetes érvényesítésével Magyarország állampénzügyei stabilizálódtak. 2011 és 2019 között az államadósság GDP-arányos mértéke 8085 százalékról 65 százalékra csökkent, míg az államadósságon belül a külföldiek részaránya lényegében megfeleződött, 66 százalékról 34 százalékra mérséklődött. Az államadósságon belüli devizaarány (amely talán a legkritikusabb tétel az árfolyamkitettség okán) 50 százalékról 17 százalékra esett vissza. Időközben 2013-tól, az államháztartási pénzügyi rendszer stabilizálásától, s legfő́képpen a növekedést támogató jegybanki intézkedések hatályba lépésétől a gazdasági növekedés $4-5$ százalékos intervallumban helyezkedett el. 2013 és 2019 között költségvetési stabilitást és gazdasági növekedést egyidejúleg volt képes az ország elérni.

Lényeges azonban hangsúlyozni, hogy az elmúlt évtized elején végrehajtott fiskális reform, majd a monetáris reform, s legfőképpen a munkahelyteremtő intézkedések, közmunkaprogramok a gazdaság stabilizálásának extenzív eszközei voltak, vagy - a kezdeti időbeliségük okán még csak - extenzív hatásokat céloztak. A hazai vállalkozásoknak juttatott állami támogatások jobbára nem voltak korszerüsítési követelményhez kötöttek, nem szorgalmazták az egyébként is alacsony hatékonyságú mikro-, kis- és középvállalatok fúzióit, annak érdekében, hogy versenyképesebb, magasabb hozzáadott értéket elóállító üzemméreteik alakuljanak ki. 2017-ben fogalmazódott meg a Magyar Nemzeti Bank részéról az a 320 pontos versenyképességi program (lásd Matolcsy 2020a), amelyben a vállalati mérethatékonyság, exportképesség javítása, a humán szektorok határozottabb minőségi fejlesztése szerepelt. A jegybank versenyképességi programja a tudásalapú gazdaság, a magas hozzáadott értéket nemzetgazdasági léptékben előállítani képes, a reform második hullámának tekinthető minőségi szempontok elérését célozta, s a nemzetközi versenyképességi szempontokat elemezte (Matolcsy 2020b; Matolcsy 2020c). A fiskális politika részéről megfigyelhető volt 2013 után, miután kikerültünk az Európai Unió Túlzott Deficit eljárásából, hogy az adócsökkentési folyamatok lefékeződtek. Nem lett egy számjegyú a személyi jövedelemadó, nem csökkent tovább a társasági nyereségadó, ami - a jelen járványválság időszakára asszociálva - erősebb tartalékokat, fizetőképes keresletet jeleníthetett volna meg, mind a lakossági, mind a kisvállalati körnél. Ám az így is eredményes előző évtized gazdaságstatisztikai számokkal is visszaigazolható teljesítményei, s a következetes jegybanki politika ellenére is a nemzeti fizetőeszközt, az ország nemzetközi adósbesorolását folyamatosan érték kedvezőtlen hatások. A külső piaci szereplők által is gyengített nemzeti fizetőeszköz, s a lefékeződő reformok egyenlegeként előállt az a helyzet, hogy önmagunkhoz, a korábbi évtizedeinkhez képest kiugróan eredményesek lettünk, ám a nemzetközi rangsorban, különösen fájóan a közép-európai térségben a felzárkózási ütemünk számos kívánnivalót hagy maga után. Lásd az 1. táblázatot, amely a javulás, felzárkózás mértékét mutatja.

\begin{tabular}{lccc} 
1. táblázat & $\begin{array}{l}\text { Az egy fớre jutó GDP vásárlóerő-paritáson az EU28 százaléká- } \\
\text { ban }\end{array}$ \\
\hline Ország megnevezése & $\mathbf{2 0 1 0}(\%)$ & $\mathbf{2 0 1 9}(\%)$ & $\begin{array}{c}\text { A felzárkózás } \\
\text { ütemének } \\
\text { változása (\%) }\end{array}$ \\
\hline Észtország & 65,3 & 83,3 & 18 \\
Lettország & 52,9 & 68,6 & 15,7 \\
Litvánia & 60,3 & 83,0 & 22,7 \\
Magyarország & 65,1 & 72,7 & 7,6 \\
Lengyelország & 62,4 & 72,4 & 10 \\
Románia & 50,9 & 69,2 & 18,3 \\
Szlovákia & 69,7 & 75 & 5,3 \\
\hline
\end{tabular}

Forrás: Eurostat, 2020 (euróadatok a GDP százalékában)

Az a körülmény, hogy régiós versenytársaink vagy megelőznek bennünket a felzárkózási ütem tekintetében, vagy eleve magasabb fejlettségi szinten állnak, mint Magyarország, ebből adódóan a gazdaságpolitikát még 
erősebb innovációt megcélzó intézkedésekre célszerú, hogy sarkallja. (Versenyképességünk mélyebb problémáit nemzetközi összehasonlításban lásd: Csaba 2018.)

\section{A válság hatásai és kezelése}

Noha a „halál éllovasának látogatásai járványok alakjában” (Bruckner 2020b) elég gyakoriak voltak Magyarországon a XX. század elejéig, könnyedén felidézhetó vagy átvehető válságkezelési metodikának e téren nem vagyunk a birtokában. Ahhoz, hogy Magyarország viszonylag nagyobb megrázkódtatások nélkül átlendüljön a válságon, megfelelő hátteret adnak a válság előtti stabil állampénzügyi alapok, és a jelenlegi válságkezelésnek az az alapfilozófiája, amely az endogén tényezők fejlesztésén keresztül próbálja elejét venni a nagyobb visszaesésnek, megtorpanásnak. Tehát a válságkezelési mód egyfajta kontinuitást mutat az előző évtized bevált gazdaságfilozófiájával és gyakorlatával. Miáltal a gazdasági alanyok alapvetően a keresletük alakulását érzékelik elsődlegesen, így a kurzus fö célja, hogy a kereslet szabályozásán (emelésén) keresztül érjen célt. Tehát nem az 1995-ben, 2006-ban, majd 2008-ban megtapasztalt fizetóképes kereslet visszafogása a jelenlegi intézkedések logikája, hanem éppen a fizetőképes kereslet bővítése. Vagyis a gazdasági szereplők részére pótlólagos forrásjuttatás, amelyből a beruházások, vásárlások fenntartása lehetséges. Ám mind a vállalati, mind a lakossági szubvenciók teljesítményhez, vagy legalább a munkaerópiaci rendelkezésre álláshoz, illetve vállalatok fenntartásához kötöttek. A magyar gyakorlat mellőzi az Egyesült Államok és számos nyugat-európai ország azon gyakorlatát, amely a szociális jövedelmek alanyi jogon történő (munkaerőpiaci aktivitáshoz nem kötött segélyalapú) folyósítását biztosítsa. Lényegében egy expanzióra építő - lásd a későbbiekben a beruházási dömpinget - gazdasági fellendülés a cél Magyarországon, amely nyilván majd nem nélkülözheti a hatékonysági követelmények érvényesítését, s egyfajta „üzletszerúséget” és modernizációt indokolt, hogy elvárjon a támogatásban részesített alanyoktól. Nyilván a visszaépítést nehezíti a korábban utalt nemzetközi versenyképességünk gyengesége, a 2017 után lefékeződött hatékonysági és versenyképességi intézkedések köre, s vele együttjáróan a fizetóképes kereslet további növelésének parlagon hagyása. A jelenlegi évtizedre jelentkező kihívás, hogy stabilizálódjanak az államháztartási pénzügyi pozíciók, elkerüljük a munkanélküliség megemelkedését, s a nemzetközi versenyképesség felfelé vivő techtonikus lemezeire (területeire) is fel tudjunk kapaszkodni, vagyis kerüljük el a közepes fejlettség csapdájába való beragadást, amelynek tengernyi a szakirodalma (lásd például: Gill-Kharas 2007; Ohno 2010; Kolozsi 2017). A közepes fejlettség csapdájában való beragadás veszélyei a járványválság idején „kiélezettebb" állami és jegybanki támogatási keretek közegében még erősebben merülnek fel, különösen akkor, ha a helyreállítási periódus elhúzódik, s a növekedési periódus pedig pénzügyi-egyensúlytalansági problémákkal lenne terhes. Vagyis, ha bármilyen okból bekövetkezik a tudásalapú gazdaságra való átállás esetleges elodázása, úgy exponenciálisan nő annak esélye, hogy Magyarország a közepes jövedelmi csapdába beragad.

A 2020-2022-es időszakban egyelőre még a helyreállítási periódusra irányulhat a figyelem. A válság kirobbanásakor különböző teóriák, alternatívák láttak napvilágot a válság típusát, lefolyását illetően. 2020 tavaszán pár hónapig tartotta magát az ún. „V” elmélet, amely a viszszapattanás logikájára épült. Vagyis a gazdaság csak rövid ideig hordja magán a válság negatív következményeit, és a mélypontot követően szinte azonnal visszatér a járványt megelőző állapot közelébe. E tétel alapvetően a 2010-2013 közötti hiperaktív fiskális, majd 2013-tól még hiperaktívabb monetáris politika lendületéből indult ki. Noha 2020 tavaszán a GDP 18-22 százalékos mértékére lett előirányozva a válságkezelési keret, ám a jobbára versenyképtelen (egyidejúleg támogatásfüggő) hazai tulajdonosi körben lévő vállalatok hiába kaptak jelentős jegybanki és kormányzati támogatást, kedvezményes hiteleket, fizetési moratóriumot, aligha voltak képesek a szúkített újratermelési fázisból a bóvített, vagy visszabővülő fázisba átmenni. Másrészt ez a gazdasági válság a járvány-fertőzés következménye, s a veszélyeztetettség elhúzódása (immár másfél éve) akadályozza a visszaépülést. $\mathrm{Az}$ „U” elmélet a „V” elmélethez hasonló következtetést fogalmaz meg, azzal a kiegészítéssel, hogy a gazdasági helyzet egy hosszabb ideig a mélyponton van, majd stabilizálódik, mielőtt végérvényesen helyreállna. A „W” elmélet pedig a gazdasági helyzet hullámvasútszerú ingadozását vetíti előre, vagyis a járvány egyes hullámainak függvényében változik a gazdaság helyzete. $\mathrm{Az}$ „L” elmélet pedig a tartós visszaesés vízióját tartja valószínúnek, amely a legkedvezőtlenebb variáns. Jobban megfogható a járványválság magyarországi kimenetele az ún. „K” elmélettel, vagyis a makrogazdasági szinten mért összesített végkifejlet helyett elsősorban a válság egyes társadalmi csoportokra, földrajzi régiókra, egyes ágazatokra és iparágakra való eltérő hatásának döntő voltára helyezi a hangsúlyt, tehát azok differenciáltságára. Igazoltnak is látszik, hogy a turizmust (Árva-Várhelyi 2020), a vendéglátást és más szolgáltató területeket érinti a válság erősebben, ám egyetlen ágazat sem kerülheti el a visszaesést, hiszen a vásárlási és beruházási hajlandóság - kifejezetten saját forrásokból - mégiscsak elbizonytalanodik, ső́t visszaesik. (A válság természetéről még bővebben: Czeczeli et al. 2020.)

Annak ellenére, hogy a jegybanki és költségvetési támogatások jobbára nem egy versenyképes kkv-szektorba kerültek, ám a válság és az intézkedések terén felismerési, válságkezelés-alkalmazási késedelem nem áll fenn. A hatékonysági késedelem, vagyis a hatékony válságkezelési intézkedések megítélése pedig csak az előző évtized függvényében értelmezhetó, ám azzal, hogy a kormány nem állt vissza a feltételek nélküli szociális juttatásokra, s helyette a munkahelyek megtartását szorgalmazta, amely 


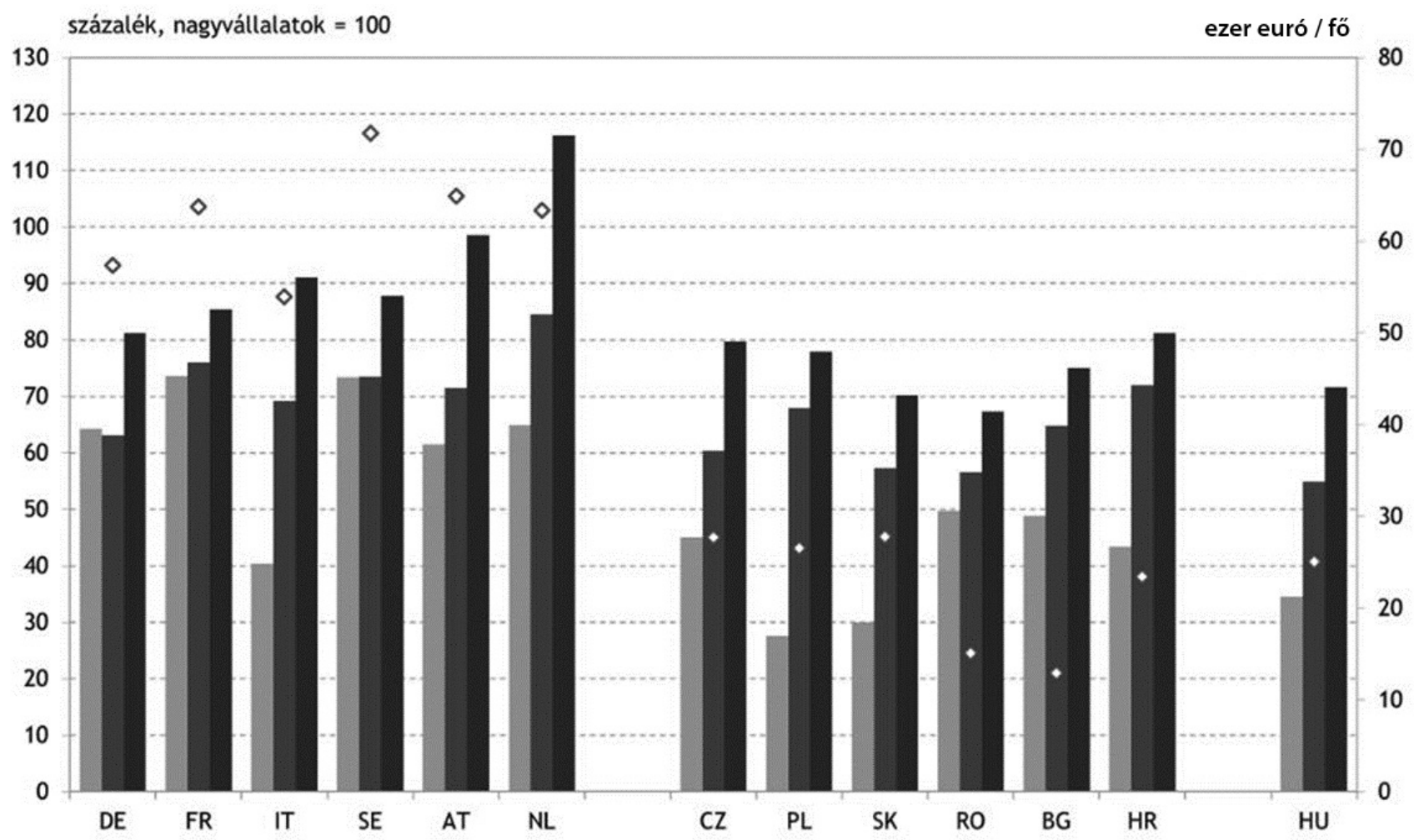

m Mikrovállalatok = Kisvállalatok = Közepes vállalatok

$\diamond$ Teljes vállalati termelékenység (jobb tengely)

\begin{tabular}{l|l} 
1. ábra & $\begin{array}{l}\text { A magyar kkv-szektor termelékenységi adatai nemzetközi összehasonlításban } \\
\text { Forrás: Magyar Nemzeti Bank, } 2020\end{array}$
\end{tabular}

optimálisnak, hatékonysági követelményeket előrevetítő döntésnek mondható.

Célszerú azonban a védekezési, majd az újraindítandó növekedési szakaszban a kis- és középvállalatok versenyképességére erősebben koncentrálni. E jobbára hazai tulajdonosi körben lévő vállalati kör az üzleti szektorban foglalkoztatottak 75 százalékát köti le, míg a GDP-nek csak 40 százalékát adja, amely önmagában is versenyképtelenségi pozícióra vall. A nemzeti és EU-s forrásokból lehívható beruházásoknak pedig 25-40 százalékát köti le. E vállalati kör termelékenységi adatai nemzetközi méretekben különösen szerénynek mondhatók. (Lásd az 1 . ábrát.) A kkv-szektornak tehát a foglakoztatási súlya jelentős, ám e vállalati kör esetleges csődjei esetén súlyos munkanélküliségi problémák alakulhatnak ki. Különösen akkor, ha a kapott támogatások ellenére sem éreznek késztetést a modernizációra, fúziókra, hatékonyságjavításra. Adódik, hogy Magyarországon talán nem is a GDP visszaesése jelenti majd a fó problémát, hanem a munkaerő tömeges kiesése a kkv-khoz köthető munkahelyekről. Hiszen a nemzetközi vállalatok szerényebben érezték meg a válságot, változatlanul tudnak fejleszteni, versenyképes üzemi méretekkel és technológiával bírnak, igaz, a munkaerő alig 20-25 százalékát foglalkoztatják, azt is a bedolgozó, velük kooperáló középvállalatokkal egyetemben. Jóllehet, e mikro- és kisvállalati kör (sok esetben 1-2 fős kényszervállalkozások) a KSH GDP-számítási módszertanában nem is szerepelnek, kvázi irrelevánsak.

A kkv-szektornak tehát a foglakoztatási súlya a jelentős, ám e vállalati kör esetleges csődjei, vagy később - az állami támogatások mérséklésével - a piacról történő „csendes” kivezetésük esetén súlyos munkanélküliségi problémák alakulhatnak ki, amely veszéllyel célszerú reálisan számolni.

\section{A költségvetési és monetáris pozíciók - válságkezelési források, veszélyek}

A 2020-as járványévet a magyar gazdaság 5,2 százalékos gazdasági visszaeséssel vészelte át. Ám a járványügyi védekezés költségei, a termelés visszaesése, $s$ velejáróan az ezt áthidaló állami támogatások hatására a költségvetési hiány is megemelkedett. Ebből adódóan a tíz év alatt leépített mintegy 15-20 százalékos GDP-arányos államadósság egy év alatt visszaépült (az államadósság „elszabaduló" vízióját lásd a 2. ábrán).

2021 nyarán már 80-85 százalékos sávban pozicionálódik a GDP-arányos államadósság, s a devizában denominált arány is újra kedvezőtlenül változik. A 2021-es évre a költségvetést 7,5 százalékos hiánycélra módosították. A 2022-es költségvetési törvény - a Költségvetési 


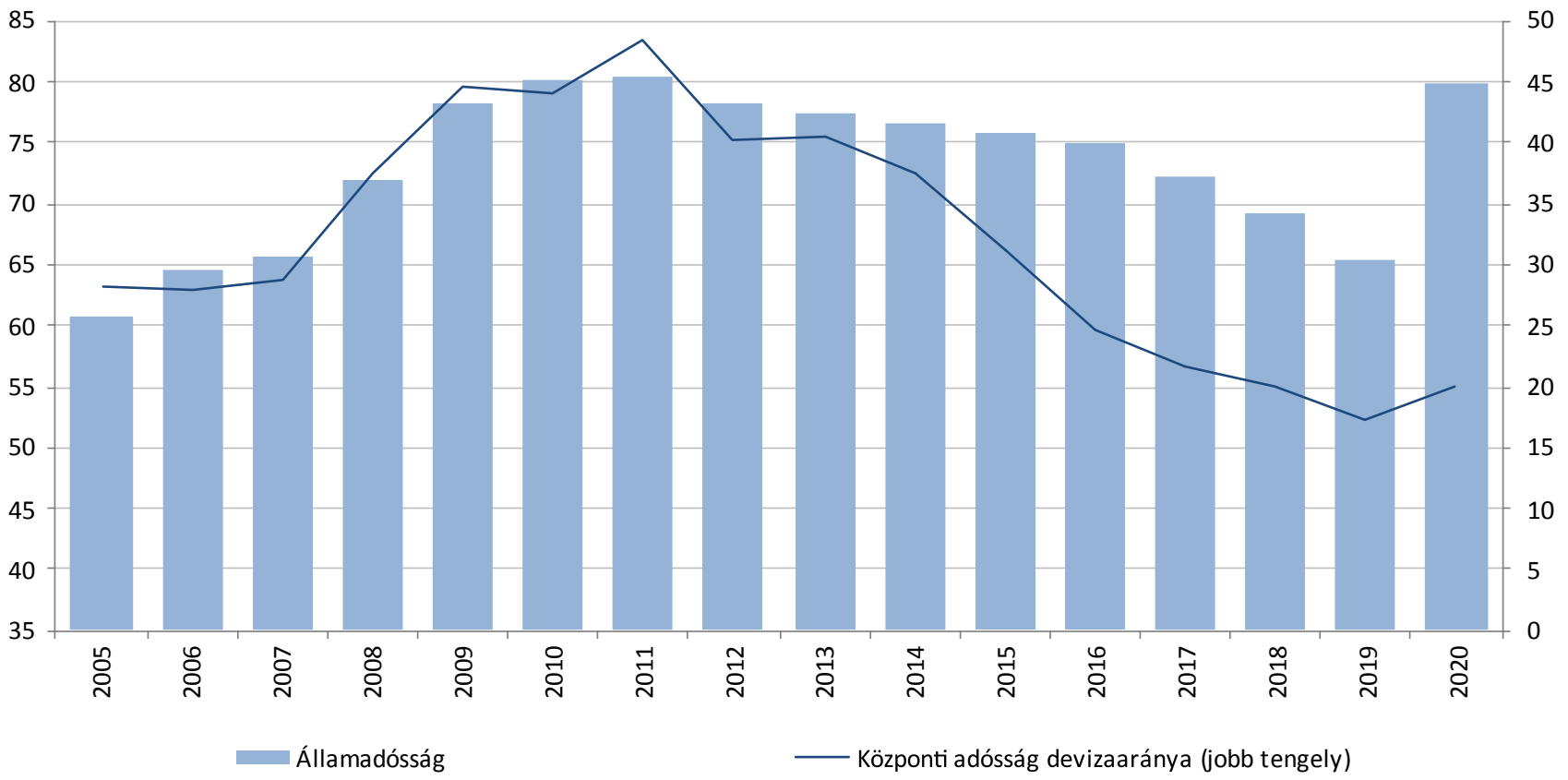

2. ábra

$$
\begin{aligned}
& \text { Az elszabaduló államadósság víziója : Az államadósság és a devizatartozás GDP-arányos mértéke, 2005-2020 } \\
& \text { Forrás: Magyar Nemzeti Bank, } 2020
\end{aligned}
$$

Tanács nemtetszését kiváltva $-5,9$ százalékos deficitet és - némi túlzott kincstári optimizmust sugallva - 79,3 százalékos adósságrátát vélelmez. A kormány által megcélzott GDP növekedési előirányzat 5,2 százalék, bár külföldi elemzők 6-6,5 százalékos megugrást is elképzelhetőnek tartanak, ám ez kétségtelenül az alacsony bázisév következménye, de visszautalva a növekedést adó belső szerkezeti-versenyképességi problémákra a helyzet korántsem kecsegtető. Vélelmezhetô, hogy a magyar gazdaság 2022 végére ugyan eléri a 2019. év végének szintjét, ám annak szerkezeti problémáival lesz terhelt. Vagyis a növekedés zömét a nemzetközi cégek adják, a kkv-szektorba öntött támogatások pedig továbbra is extenzív hasznosulást biztosíthatnak csak. Mindezek tükrében a fiskális politika gazdasági ösztönző funkcióinak az erôsítése, az emelkedő állampapírpiaci kamatok és a devizaarány növekedése miatt az adósság-menedzsment és a versenyképességet ösztönző politika kiemelt szerepkörbe kellene hogy kerüljenek.

A részben beruházási célokra megemelt állami kiadások, továbbá az Európai Uniótól érkező - 2021-ben a GDP 2,7 százalékát kitevő, mintegy 1500 milliárd forintnak megfelelő - nettó közös költségvetési támogatás, továbbá az EU Újjáépítési alapján igényelt 2500 milliárd forintnak megfelelő - egyébként jogállamisági feltételekhez kötött, így korántsem biztos - támogatás, illetve a kínai és orosz partnereinktól beruházási célokra igényelt mintegy 4000 milliárd forintnak megfelelő összeg az egyébként is magas beruházási hányadot megvalósító magyar gazdaságba igazi beruházási dömpinget, s vele járóan inflatorikus és külgazdasági problémákat (is) okozhat. Magyarország beruházási rátája az elmúlt években GDP-arányosan 28 százalékos volt, s az állami beruházási ráta is 6,5 százalékos. Egyrészt az erős beruházási aktivitás, másrészt a lakossági jövedelmek jövőre (is) vonatkozó magas növelési előirányzatai a fizetóképes keresletet számottevően tovább emelik, amely gazdasági-keresleti túlfútöttséget okoz, amely inflációs nyomással jár. Az erôs - nehezen kezelhető - beruházási multiplikátor várhatóan tovább rontja a már messze nem pozitív fizetési mérleget és a külkereskedelmi mérlegpozíciókat is, hiszen a külföldi vásárlások emelkedése igen nagy fokban valószínúsíthető. A hozzávetőleg 50000 milliárd forintos magyar GDP-hez mérten e beruházási tételek magasak, és jelentős inflációs nyomást is okoznak, amelyre a monetáris politika eszközeivel az ellensúlyozó lépések el is kezdődtek, részben a vállalati refinanszírozási tételek visszafogásával, és az alapkamat-emeléssel. Az önmérséklet jeleként is értékelhető, hogy az amúgy is tetemes beruházási forrásokon túlmenően a kormány - egyelőre nem igényelte az EU Újjáépítési alapjából lehívható 3384 milliárd forintnak megfelelő hitelkvótát.

A nemzetközi monetáris térben lezajló folyamatokat (lásd Borio-Disyatat 2021) és a Magyar Nemzeti Bank legújabb reakcióit figyelve, konstatálható, hogy a drasztikusan emelkedő államadósság és infláció a jegybankokat, így a magyart is, az előző évtizedben vitt expanzív monetáris politika felülvizsgálatára késztetheti. A hangsúly a fiskális politika tartalékjaira, helyenként az önmérsékletére, sőt a hiány esetleges elengedésének fékezésére, s a költségvetési tanácsok fegyelmező erejére összpontosul, miközben a monetáris politikának (immár helikopter 
pénzek helyett) az ár- és pénzügyi stabilitásra kell fókuszálni, amivel a fenntartható fejlődést (klasszikusan) tovább szolgálhatja. A jegybankoknak konszolidálni, semlegesíteni kell az esetleg nem túl erős fiskális fegyelmet gyakorló kormányok költségvetési hiányaiból adódó inflatorikus hatásokat. Időközben, óhatatlanul a fiskális politika figyelme pedig a növekedésre, a gazdaság megfelelő szerkezetére is indokolt, hogy koncentráljon. A COVID-19 válság előtérbe helyezte a monetáris és fiskális politika közötti más típusú (egyirányú keresletélénkítő hatás helyetti differenciált) szempontokat, szembesülve egy példátlan gazdasági összeomlással. A két politika az elmúlt évtizedben „simán” múködött együtt. De vannak kérdések, vajon folytatják-e ezt a válság elhalványulásával és az esetleges feszültségek következményeivel kapcsolatban.

A jegybankok, így a Magyar Nemzeti Bank szerepköre is az új típusú monetáris pályán a hagyományos infláció moderáló szerepkörön túlmenően (azt nem veszélyeztetve) irányulhat a megújuló, valóban korszerúbb gazdasági szerkezet kiépítésére. Emberöltőnket a válság után a globalizáció új irányai, a digitalizáció, a növekvő adósságok kezelése, a pénz forradalma, a zöldgazdaság, az átalakuló fogyasztói szokások, az öregedő társadalommal jelentkező problémák/kihívások uralják majd. Várhatóan lerövidülnek a globális értékláncok, a beszállítói bázisok diverzifikálódnak, a gyártáshoz szükséges biztonsági készletek megemelkednek. A digitális gazdaság - amely Magyarországon jelenleg a GDP 8 százalékát adja - lesz a XXI. század nyersanyaga, vagyis a nyersanyag helyett az adat lesz az új központi erőforrás. Valószínúleg az Európai Unión belüli belső feszültségek, az Észak és Dél közötti törésvonalak felerősödnek. A kihívásokra várhatóan egyre inkább lokális válaszok születnek, s a nemzetközi intézmények szerepe akár halványulhat is. A kelet-közép európai térség szerepe felértékelődhet a várható (relatív) stabilitása és a prosperitása révén. A globális termelésszervezéssel járó kockázatok mérséklésével elötérbe kerülhet a back to basic szemlélet, vagyis a természetes környezet, s a belőle fakadó előnyök kihasználása. Látva a nemzetközi kereskedelmi láncok által eddig biztosított élelmiszer- és energiaellátás kockázatait, az országok többsége törekedni fog a saját élelmiszer- és energiabiztonság előremozdítására. Nyilván e techtonikus lemezekre való „felpattanáshoz" versenyképes, innovatív, e folyamatokban részt venni képes vállalatokra lesz szükség, s nem olyanokra, amelyek államitámogatás-függők, s a minimálbér esetleges emelésének kigazdálkodása is problémát okoz. A Magyar Nemzeti Bank e szempontok mentén „araszolja” új típusú monetáris politikáját, amelynek egyik fó eredménye máris a fenntartható gazdaságpolitika előmozdítására irányuló kritérium beépítése a jegybanktörvénybe, vagyis a jegybank fenntarthatósági mandátumot kapott, negyedik monetáris céljaként. A COVID-19 válság nyomán még inkább előtérbe kerülő „zöld fordulat” elősegítése a pénzügyi szektor és a jegybankok számára is kiemelt feladatot jelent. A központi bankok sem hagyhatják figyelmen kívül a klímaváltozást, erre reagálniuk kell, ám a jegybanki szerepvállalás mértékét illetően további egyeztetésre és tapasztalatmegosztásra van szükség. A zöld megújulás, a körforgásos gazdaság erősítését a COVID-19 jelentősen „előre hozta”, hiszen a járványhelyzet új lehetőséget teremt a zöld és digitális átalakulás számára, amelynek megvalósítása nemzetközi együttmúködés keretei között hatékonyabb, ám ehhez egy adott országnak érdemi partnerré (résztvevővé) kell válnia. A jegybanki monetáris eszköztár e célokra fókuszáltan tudja a gazdasági és társadalmi stabilitást szolgálni a pénzügyi egyensúly és a növekedésre késztetés által, s nem pedig az elmúlt évtizedben vitt mennyiségi lazítási (extenzív) politika (kizárólagos) tovább folytatásával.

\section{Konklúzió}

Amennyiben a korábbi évszázadok járványait vizsgáljuk, elmondható, hogy az alapvető túlélési stratégia a helyben maradás volt, amely a jelenlegi túlmozgásos társadalom esetében nehezen kivitelezhető. Ám a jelenlegi válság mégiscsak a lokális, nemzetgazdasági szerepek felértékelődését hozhatja az „erősebb” és „célra tartóbb” (helyi célokra erősebben fókuszáló) fiskális és monetáris politika által. A járványok később demográfiai változásokat (népességszám növekedést) váltottak ki, az elhalálozott népesség pótlására, sőt, létszámbeli meghaladására, sőt az etnikai eltolódások (migráció) is gyakori volt. És aki túlélte a járványt, erősebb, tapasztaltabb lett elődjeinél, hiszen nagyobb életerővel rendelkezett, s általuk növekedtek az erőforrások. A mezőknek kevesebb embert kellett eltartani, az erdőkben több vad lett, több hús kerülhetett a járványt túlélt családok asztalára, csökkent a gyermekhalálozás, s később, már a kapitalizmus idején, mivel csökkent a munkáslétszám, az erősebb munkaerőpiaci kereslet hatására emelkedtek a bérek. Például a pestisjárvány „utat nyitott a reneszánsz számára”, „a 19. század első felében a hazánkat is pusztító nagy kolerajárványok hatására 1851-től kezdve a járványok elleni védekezés jegyében egészségvédelmi konferenciákat tartottak" (Bruckner 2020a alapján).

A COVID-19 válság vélhető hatása az állampénzügy területére talán abban határozható meg, hogy a 20072008-as válság után több mint egy évtizeden át a menynyiségi lazításba „fulladó” monetáris politikák és a versenyképességi szempontokat kevésbé szem előtt tartó fiskális szabályozás (lásd különösen Magyarország esetét) új kihívással szembesül. El kell érni, hogy a közpénzt, a jegybankpénzt csak az igazán hatékony, jól hasznosuló területekre lehessen fordítani. A kelet-közép-európai poroszos normakövető fiskális és monetáris szabályozás helyébe a társadalmi, nemzetgazdasági, vállalati hatékonyságot javító megoldások lépjenek. 


\section{Irodalomjegyzék}

Árva L. \& Várhelyi T. (2020) Elmozdulás a minőségi turizmus felé. A fenntarthatóság a turizmusban a koronavírus járvány után. Polgári Szemle, Vol. 16. No. 1-3. pp. 94-114.

Bruckner É. (2020a) A történelem hajtóostorai, a járványok. Polgári Szemle, Vol. 16. No. 1-3. pp. 36-56.

Bruckner É. (2020b) A halál lovasának látogatásai járványok alakjában Magyarországon. Polgári Szemle, Vol. 16. No. 4-6. pp. 67-87.

Borio, C. \& Disyatat, P. (2021) Monetary and Fiscal Policy: Privileged Powers, Entwined Responsibilities. SUERF Policy Note Issue No. 238, May 2021, p. 12. https://www.suerf.org/docx/ f_bb36e395b063bec9205952807471e86a_24711_suerf.pdf [Letöltve: 2021. 07. 10.]

Botos K. (2020) A koronavírus válság és a világ régiói. Polgári Szemle, Vol. 16. No. 4-6. pp. 51-66.

Csaba L. (2018): Válság - Gazdaság - Világ. Adalék Közép-Európa három évtizede gazdaságtörténetéhez. Éghajlat Kiadó

Domokos L. (2019) Ellenőrzés - a fenntartható jó kormányzás eszköze. Akadémiai Kiadó

Czeczeli V., Kolozsi P. P., Kutasi G. \& Marton Á. (2020) Economic Exposure and Crisis Resilience in Exogenous Shock: The ShortTerm Economic Impact of the Covid-19 Pandemic in the EU. Public Finance Quarterly, Vol. 65. No. 3. pp. 321-347.

Földes B. (1885) A nemzetgazdaság és pénzügytan kézikönyve. Második átdolgozott kiadás. Zilahy Sámuel nyomdájában. 320. o.

Gill, I. \& Kharas, H. (2007) An East Asian Renaissance: Ideas for Economic Growth. Washington, DC: World Bank. (c) World Bank. https://openknowledge.worldbank.org/handle/10986/6798 (letöltve: 2021. június 15.)

Indermit, G. \& Homi, K. (2015) The Middle-Income Trap Turns Ten. World Bank. Policy Research Working Paper, 7403 August
2015. Washington. https://openknowledge.worldbank.org/bitst ream/handle/10986/22660/The0middle0income0trap0turns0ten.pdf? sequence $=1$ \&isAllowed $=y$ [Letöltve: 2021.07 .10 .]

Kolozsi P. P. (2017) How Can We Escape the Middle Income Trap? Public Finance Quarterly (1963-) Vol. 62. No. 1 pp. 74-87.

Kornai J. (2006) The Great Transition of Central Eastern Europe: Success and Disappointment. Economics of Transition. Vol. 14. No. 2. pp. 207-244.

Lentner Cs. (2016) Rendszerváltás és pénzügypolitika. Tények és tévhitek. Akadémiai Kiadó

Lentner Cs. (2019) A magyar állampénzügyek fejlődéstörténete a dualizmus korától napjainkig. Európától keletre, Ázsiától nyugatra. L'Harmattan

Matolcsy Gy. (2020a) Egyensúly és növekedés 2010-2019. Második átdolgozott kiadás. Magyar Nemzeti Bank

Matolcsy Gy. (2020b) Quo vadis Hungaria - Facing a New World. Civic Review, Vol. 16, Special Issue, pp. 9-31.

Matolcsy Gy. (2020/c) Competitiveness as a Decisive Criterion for Sustainability. Public Finance Quarterly, Vol. 65. No. 2. Special Edition, pp. 7-24.

Ohno, K. (2010) Avoiding the Middle Income Trap: Renovating Industial Policy Formulation in Vietnam. ASEAN Economic Bulletin, Vol. 26. No. 1. pp. 25-43. https://www.grips.ac.jp/vietnam/ KOarchives/doc/EP32_ADB_HQ_MIT.pdf [Letöltve 2021. 07. 10.]

Ohno, K. (2010) The Middle Income Trap Implications for Industrialization Strategies in East Asia and Africa. https://www.grips.ac. jp/forum-e/pdf_e08/TheMiddleIncomeTrap.pdf (letöltve: 2021. június 15.)

Virág Barnabás (2020) (szerk.) Tízszer tíz év - számokban. Magyarország elmúlt száz évének gazdaságtörténete. Magyar Nemzeti Bank

A cikk a Creative Commons Attribution 4.0 International License (https://creativecommons.org/licenses/by/4.0/) feltételei szerint publikált Open Access közlemény, melynek szellemében a cikk bármilyen médiumban szabadon felhasználható, megosztható és újraközölhető, feltéve, hogy az eredeti szerző és a közlés helye, illetve a CC License linkje és az esetlegesen végrehajtott módosítások feltüntetésre kerülnek. (SID_1) 